\title{
JOTSE AND QUALITY INVESTIGATIONS
}

\author{
Beatriz Amante Garcia ${ }^{1}$, María Martínez Martínez ${ }^{2}$ (D) \\ ${ }^{1}$ Projectes d'Enginyeria, Universitat Politècnica de Catalunya (Spain) \\ ${ }^{2}$ Enginyeria Química, Universitat Politècnica de Catalunya (Spain) \\ beatriz.amante@upc.edu, rosario.martinez@upc.edu
}

\section{Editorial}

During this last term JOTSE participated in XIII Foro Internacional sobre la Evaluación de la Calidad de la Investigación y de la Educación Superior (FECIES) [plenary sesion: http://www.ugr.es/ aepc/FECIES 13/]. This forum deeply discussed issues on teaching and research quality as they are two key subjects, which are always present in the papers published in our Journal. In order to assess how much research is needed to be a good university teacher, we analyze these subjects by means of a survey (https://goo.gl/9g60at) to JOTSE's contributors. (Figure 1)

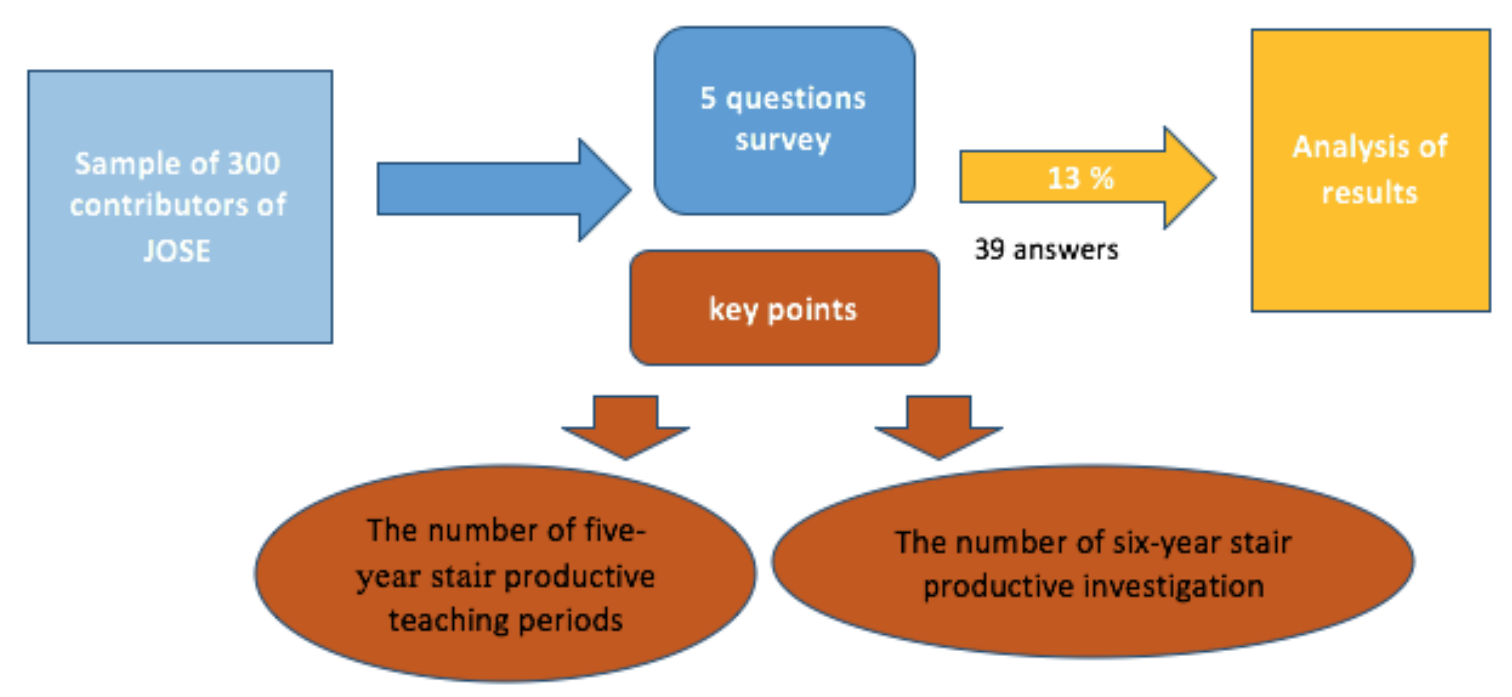

Figure 1. Methodology 
The survey shows that the number of five-year stair productive teaching periods are fairly uniform, although the amount of 4 and 5 periods is abundant, which is consistent with the age range of contributors who responded, as more than $50 \%$ are over 50 years old and about $70 \%$ are "professors and lecturers". However, the percentage of productive investigation stairs does not follow the same relation, being mostly concentrated on 1, 2 or 4 . Results were treated statistically to find significant correlations.

Figure 2 shows that about $51.2 \%$ of responders from JOTSE disagree and strongly disagree with the claim that a good teacher has to be a good researcher. Further, disagreement is more frequent on women and on responders older than 60 years in comparison to men and young people (3040).

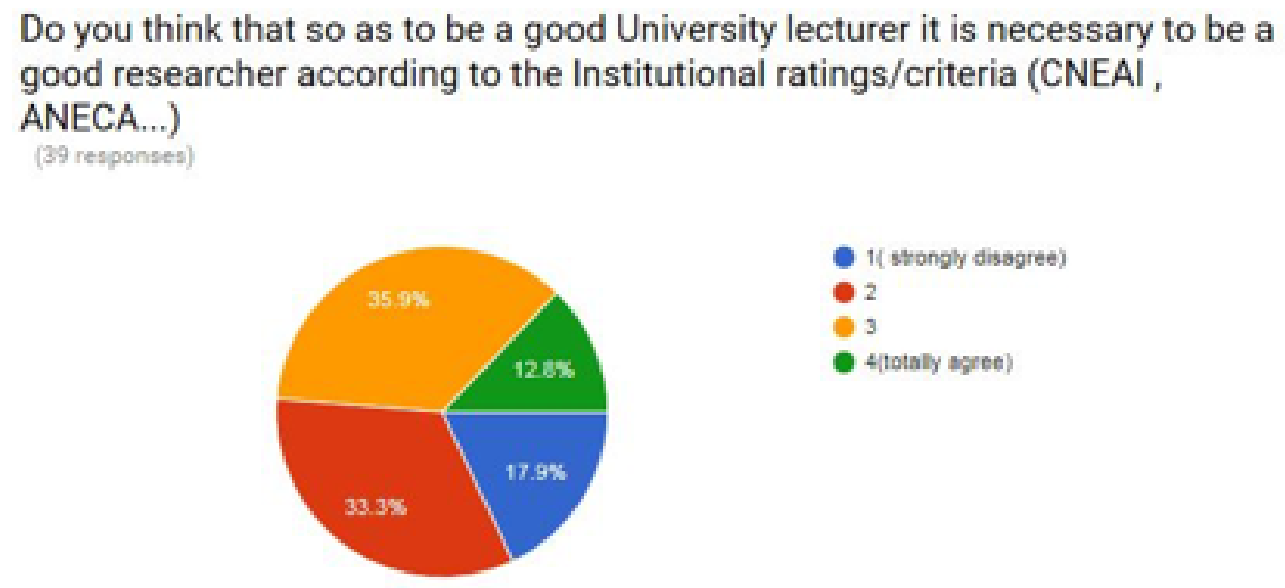

Figure 2. Answers to the question "It is necessary to be a good researcher to be a good University lecturer?

The present issue counts on the following published articles:

- Teaching complicated conceptual knowledge with simulation videos in foundational electrical engineering courses by Baiyn Chen, Lei Wei and Huihui Li.

- Interactive online physics labs increase high school students' interest by Patrick Gryczka, Edward Klementowicz, Chappel Sharrock and Jin Kim Monclare.

- Online quizzes in a virtual learning environment as a tool for formative assessment by Donita Cohen and Irit Sasson. 
- Science learning motivation as correlate of students' academic performances by Nhorvien Jay P. Libao, Jessie John B. Sagun, Elvira A. Tamagan, Agaton P. Pattalitan Jr., Maria Elena D. Dupa and Romiro G.Bautista.

- Validation of a questionnaire on research-based learning with engineering students by Fabián Cobos Alvarado, Mónica Peñaherrera León and Ana María Ortiz Colon.

We hope that you find them interesting.

Published by OmniaScience ( $\underline{\text { www.omniascience.com }}$ )

Journal of Technology and Science Education, 2016 (www.jotse.org)

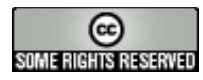

Article's contents are provided on an Attribution-Non Commercial 3.0 Creative commons license. Readers are allowed to copy, distribute and communicate article's contents, provided the author's and JOTSE journal's names are included. It must not be used for commercial purposes. To see the complete licence contents, please visit http://creativecommons.org/licenses/by-nc/3.0/es/ 